\title{
Indigenous Language Immersion Schools for Strong Indigenous Identities
}

C 2011, Jon Reyhner, Northern Arizona University ${ }^{1}$

This article examines evidence from indigenous language immersion programs in the United States and makes the case that these immersion programs are vital to healing the negative effects of colonialism and assimilationist schooling that have disrupted many indigenous homes and communities. It describes support for immersion programs by American Indian leaders and how these programs are furthering efforts to decolonize indigenous education and helping further United Nations policies supporting the rights of indigenous peoples. The fit between place-, community-, and culture-based education and immersion language programs is described with examples from Apache, Ojibwe, Diné (Navajo), Hawaiian, and Blackfeet language programs illustrating how traditional indigenous values are infused into language programs to help build strong positive identities in indigenous students and their communities.

International support for decolonization and the rights of indigenous peoples was formalized on September 13, 2007 when the United Nations (UN) adopted the Declaration on the Rights of Indigenous Peoples by a vote of 143 to 4, with only Canada, Australia, New Zealand, and The United States in opposition. ${ }^{2}$ Article 2 of this declaration affirms, "Indigenous peoples have the right of self-determination." Other articles declare more specific rights; for example,

${ }^{1}$ A shortened version of this paper appeared in the fall 2010 issue of the Heritage Language Journal (Vol. 7 No. 2, pp. 138-152).

${ }^{2}$ Since then all four of these countries have issued statements reversing their position and supporting the declaration. 
"the right not to be subject to forced assimilation or destruction of their culture" (Article 8); "the right to revitalize, use, develop and transmit to future generations their histories, languages, oral traditions, philosophies, writing systems and literatures, and to designate and retain their own names for communities, places and persons" (Article 13) and "the right to establish and control their educational systems and institutions providing education in their own languages, in a manner appropriate to their cultural methods of teaching and learning" (Article 14).

In keeping with the 2007 Declaration, the UN's General Assembly made 2008 the “International Year of Languages.” UNESCO Director-General Kö̈chiro Matsuura (2008) stated, "Languages are indeed essential to the identity of groups and individuals and to their peaceful coexistence. They constitute a strategic factor of progress towards sustainable development and a harmonious relationship between the global and local context." He further noted that the ninth International Mother Language Day (February 21, 2008) would "have a special significance and provide a particularly appropriate deadline for the introduction of initiatives to promote languages."

These recent UN initiatives build on the UN's 1948 Universal Declaration of Human Rights that states in Article 26 that "Parents have a prior right to choose the kind of education that shall be given to their children" and the 1992 Declaration on the Rights of Persons Belonging to National or Ethnic, Religious and Linguistic Minorities, which declared in Article 1 that "States shall protect the existence and the national or ethnic, cultural, religious and linguistic identity of minorities within their respective territories and shall encourage conditions for the promotion of that identity." Article 2 affirms that "Persons belonging to national or ethnic, religious and linguistic minorities...have the right to enjoy their own culture, to profess and practice their own religion, and to use their own language, in private and in public, freely and 
without interference or any form of discrimination.” The following year was declared by the UN to be the "International Year of the World's Indigenous People."

However, the international support that UN declarations appear to signal often does not extend beyond rhetoric. Tove Skunabb-Kangas (2000, p. 492) finds that "many governments applaud...human rights, as long as they can define them in their own way, according to their own cultural norms." She notes that the United States in particular had only ratified 15 of 52 universal human rights instruments as of 1998, putting it far down on a list, accompanied by Somalia and just below Saudi Arabia, that is led by Norway with 46 ratifications (see also Reyhner, 2008).

Despite the U.S. government's failure to support U.N. declarations supporting the rights of indigenous peoples, efforts restoring indigenous values and language are ongoing among American Indian activists, who are focusing on decolonizing Indian education (Grande, 2004). The goal of this decolonization is to move beyond a mentality of victimization and heal the historical wounds suffered by colonized peoples. Native language immersion schools have become a key part of the post-colonial healing process that seeks to restore and strengthen Native families and communities. These programs seek to redress the abuse indigenous languages historically carried out by assimilationist schooling while using the power of the language to convey tribal values. A key feature of indigenous immersion programs is that they are voluntary, allowing parents who choose to enroll their children in them to exercise a basic human right upheld by the United Nations' initiatives and declarations on indigenous peoples. This paper examines evidence from several programs in the U.S. to understand their role in healing the negative effects of colonialism that have disrupted many indigenous homes and communities. 


\section{Assimilation and its Effects}

For most of the history of the United States, the basic human rights delineated by the UN in 1948 and 1992 have been denied to ethnic minorities; in fact, it was government policy to assimilate them into the dominant English-speaking population through schools in which their native languages and cultures were suppressed. Schools were used for centuries to eliminate indigenous languages by punishing students who spoke them and indoctrinating them into the superiority of English as compared to their "barbarous dialects" and into Christianity compared to their "barbarous beliefs" (Adams, 1995; Reyhner \& Eder, 2004).

Starting with the 1928 Meriam Report (Institute), an independent comprehensive study of the U.S. Indian Office by the Brookings Institute for Government Research at John Hopkins University, studies have shown the harm done by this assimilationist policy to indigenous students and their academic achievement, which has lagged far behind U.S. national averages.

The National Center for Education Statistics' report, Status and Trends in the Education of American Indians and Alaska Natives (Freeman \& Fox, 2005), found indigenous students with more than twice the White dropout rate, the highest death rate of 15-19 year olds, the highest percentage of special education students, and the highest absenteeism. These students are also the most likely to have failed to complete core academic programs in their schools, and the most affected by school violence. These grim statistics are tinged with irony given that the U.S. government's past English-only policy in schools has been so successful that $51 \%$ of American Indian and Alaska Native eighth graders reported in 2003 never speaking any language but English at home and only $22 \%$ reported speaking a non-English language half the time or more (Freeman \& Fox, 2005). 
The challenges facing modern Indians extend beyond the classroom walls.

Unemployment among Native people is three times the national average (Freeman \& Fox, 2005).

Gang activity is prevalent and incarceration rates are high. This social and economic plight is a direct result of the destruction of American Indian families and communities brought about by assimilationist policies.

When an Ojibwe (aka Anishenabe or Chippewa) high school student on the Red Lake Reservation in Minnesota shot and killed a teacher and seven students in 2005, Navajo Nation President Joe Shirley emphasized how poverty and the breakdown of traditional tribal culture helped make such a tragedy possible. He wrote,

We are all terribly saddened by the news about our relatives on their land in Red Lake in Minnesota. Unfortunately, the sad truth is, I believe, these kinds of incidents are evidence of natives losing their cultural and traditional ways that have sustained us as a people for centuries.

Respect for our elders is a teaching shared by all native people. In the olden days we lived by that. When there was a problem, we would ask, "What does Grandpa say? What does Grandma say?"

On many native nations, that teaching is still intact, although we see it beginning to fade with incidents like this.

Even on the big Navajo Nation, we, as a people, are not immune to losing sight of our values and ways. Each day we see evidence of the chipping away of Navajo culture, language and traditions by so many outside forces. 
Because we are losing our values as a people, it behooves native nations and governments that still have their ceremonies, their traditions and their medicine people, to do all they can to hang onto those precious pieces of culture. That is what will allow us to be true sovereign native nations. This is what will allow our people to stand on our own. The way to deal with problems like this one is contained in our teachings. (Shirley, 2005, p. 5)

Joy Harjo, a member of the Muscogee Creek tribe, sums up the end product of this systematic dismantling of culture and the linguistic means of transmitting it: "Colonization teaches us to hate ourselves. We are told that we are nothing until we adopt the ways of the colonizer, until we become the colonizer" (as quoted in Mankiller, 2004, p. 62). This is a tragic legacy of assimilationist policy.

\section{Language, School and Assimilation}

Any effort at revitalizing indigenous languages in schools will have to overcome the deep suspicion that some Indigenous people harbor towards schooling. American Indians and other Indigenous peoples distrust schools because historically they have been colonial instruments designed to eradicate Native languages and to assimilate Indians into the white, Euro-American, and Christian culture (Adams, 1995; Reyhner \& Eder, 2004).

Whether government- or missionary-run, the goal of schools was to replace indigenous community and family values with a new set of ideals. While government-sponsored institutions saw education and suppression of the native language as a means of assimilation, religiously affiliated schools viewed the imposition of English as a means of conversion to Christianity. 
Conversion and assimilation tore tribal communities and families apart as some members hung on to cherished traditions, whereas others rejected those traditions as outdated, the work of the devil, and/or "savage."

In her 1999 autobiography The Scalpel and the Silver Bear, Lori Arviso Alvord, the first Navajo woman surgeon, described her grandmother's and father's schooling, during which they were punished for speaking Navajo and "told by white educators that, in order to be successful, they would have to forget their language and culture and adopt American ways" (Alvord \& Van Pelt, p. 86). She concluded "two or three generations of our tribe had been taught to feel shame about our culture, and parents had often not taught their children traditional Navajo beliefs--the very thing that would have shown them how to live, the very thing that could keep them strong" (Alvord \& Van Pelt, p. 88).

Dillon Platero, the first director of the Navajo Division of Education, , reports the deleterious effects of a similar language policy, describing its effects on a typical Navajo student, "Kee,":

Kee was sent to boarding school as a child where--as was the practice--he was punished for speaking Navajo. Since he was only allowed to return home during Christmas and summer, he lost contact with his family. Kee withdrew from both the White and Navajo worlds as he grew older because he could not comfortably communicate in either language. He became one of the many thousand Navajos who were non-lingual--a man without a language. By the time he was 16 , Kee was an alcoholic, uneducated, and despondent--without identity. (Platero, 1975, p. 58) 
Platero concludes his description of Kee by emphasizing the need to use the Navajo language more in teaching Navajo students.

Speaking at the U.S. Office of Indian Education's Language and Culture Preservation Conference in Albuquerque, New Mexico in 2004, former Menominee Tribal Chairperson Apesanahkwat recalled that in Catholic school the nuns, in effect, told their students "to throw stones at the elders." He opined that Indians today "have tasted cherry pie [the good things of modern America] and we like it." However, Indians today are "like fish lying on the beach... we need to be in that water" of their culture. Apesanahkwat, like Arviso and Platero and others, argues that indigenous cultures are inextricably intertwined with the survival of the people, and that when those cultures suffer attack, the survival of the people is jeopardized.

\section{Support for the Revitalization of Indigenous Languages}

Many American Indian leaders have expressed their support for their indigenous languages. At the 2005 annual meeting of the National Indian Education Association, Cecelia Fire Thunder, President of the Oglala Sioux at Pine Ridge, testified, "I speak English well because I spoke Lakota well... Our languages are value based. Everything I need to know is in our language." She declared that language is more than communication: "It's about bringing back our values and good things about how to treat each other." Sisseton Wahpeton tribal college president Dr. William Harjo LoneFight declares, "When people spoke Dakota, they understood where they belonged in relation to other people, the natural world, and to the spiritual world. They truly knew how to treat one another" (as quoted in Ambler, 2004, p. 8).

Sally Midgette (1997, p. 39) writes, "I have heard several Native Americans speak feeling about their sense of rootlessness and despair, and how they recovered when their 
grandmothers taught them to speak Tolowa, or Navajo, and they regained a sense of themselves and their heritage." Interviewing Navajo elders in their own language, Dr. Evangeline Parsons Yazzie (1995, p. 3) found, "Elder Navajos want to pass on their knowledge and wisdom to the younger generation. Originally, this was the older people's responsibility. Today the younger generation does not know the language and is unable to accept the words of wisdom" (Yazzie, 1995, p. 3). She concluded, "The use of the native tongue is like therapy, specific native words express love and caring. Knowing the language presents one with a strong self-identity, a culture with which to identify, and a sense of wellness" (Yazzie, 1995, p. 3). An elder told her, "television is robbing our children of language" (Yazzie, 1995, p. 135). As indigenous children learn English or other "National" languages and cultures through the media and in schools, they increasingly become separated from their heritage, and some cannot speak to their grandparents. One of Yazzie's informants told her, "Older people who speak only Navajo are alone” (Yazzie, 1995, p. 4). Many American Indians see language as the key to their identity, and they question whether one can be Cherokee, Navajo, Crow, Seminole, and so forth without speaking their tribal language.

Northern Cheyenne educator Richard Littlebear found,

Our youth are apparently looking to urban gangs for those things that will give them a sense of identity, importance, and belongingness. It would be so nice if they would but look to our own tribal characteristics because we already have all the things that our youth are apparently looking for and finding in socially destructive gangs. We have all the characteristics in our tribal structures that will reaffirm the identities of our youth. Gangs have distinctive colors, clothes, music, heroes, symbols, rituals, and "turf".... We 
American Indian tribes have these too. We have distinctive colors, clothes, music, heroes, symbols, and rituals, and we need to teach our children about the positive aspects of American Indian life at an early age so they know who they are. Perhaps in this way we can inoculate them against the disease of gangs. Another characteristic that really makes a gang distinctive is the language they speak. If we could transfer the young people's loyalty back to our own tribes and families, we could restore the frayed social fabric of our reservations. We need to make our children see our languages and cultures as viable and just as valuable as anything they see on television, movies, or videos. (1999, pp. 4-5)

\section{The Focus of Immersion Programs - Restoration of Traditional Values or Preparation for the Larger Society?}

Educational reformers advocate immersion programs which would teach subject matter in the native language. It is not enough, however, to simply introduce the native language if a school's curriculum remains unchanged (Nevins, 2004). Just translating a non-Native curriculum into the Native language and focusing on vocabulary and grammar is in no way part of a decolonization agenda. In fact, it could be viewed as nothing more than a new way to approach colonization. On the other hand, if the non-Native curriculum is ignored as language revitalization programs are implemented, students will be denied access to the skills needed to negotiate the larger society and participate in the modern economy. In addition, reversing the longstanding assimilationist policy may engender confusion and deep suspicion among Native peoples who accommodated to the pressures they faced by assimilating into the dominant culture, for example by converting to Christianity. The views of some Christian Natives who see language revitalization programs as possibly revitalizing Native religions need to be considered 
(see e.g., Yazzie, 2003). One example that can be viewed as a compromise comes from Hawaiian activists, whose goal in language revitalization is to restore the "Hawaiian philosophy of life" and incorporate its values into the curriculum instead of teaching traditional Hawaiian religion. Some educators, however, are uncomfortable with the premise that curriculum can be balanced so that students "can live in two worlds." LaDonna Harris (a member of the Comanche tribe) remarks, "It drives me crazy when people say we have to live in two worlds. We can't live in two worlds. We have to live in one world and carry those values with us and live them every day wherever we live. People become dysfunctional when they adopt situational values" (as quoted in Mankiller, 2004, p. 68-69). Oglala Sioux educator Dr. Sandra Fox also hates "the 'walk in two worlds' idea; the time you should be most Indian is in the white world" (as quoted in Reyhner, 2006c). Like Harris, Fox wishes to foster traditional tribal values, which usually include cooperation, generosity, reciprocity, respect, and humility, and emphasize our relatedness to all things and the need for balance and harmony. These cultural values cannot be taught just as a thing of the past as children are growing up in and must live in the present.

Nevins (2004) in her study of Apache language revitalization notes, "While babies are praised, coddled, humored, and generally celebrated, in many ways this early indulgence sets them up for important lessons in humility and modesty of self-representation" between ages two and four (p. 278). All traditional societies harbor similar types of collective wisdom of time tested child rearing skills that teach youth how to interact with others and what it means to be a human being that they handed down from generation to generation.

Kyril Calsoyas for his 1992 doctoral dissertation, The Soul of Education: A Navajo Perspective, interviewed Navajo elder and medicine man Thomas Walker, who critiques the values fostered in non-Navajo education. 
For over one hundred years the white man has defined what education will be for the Navajo people.... I was brought up with the old philosophy and what I see now with the White Men's way in today's world there is a wide difference and the intent of education does not relate any more. Because of this, in this present time, the children that are taught whatever is real, the old philosophy does not touch. The old language does not touch on these things. The children are given too much power. Whenever you try to correct a child from wrongdoings it becomes difficult to discipline them because of the laws that have been developed to protect children from abuse. When one is trying to discipline a child they say that they are being called names and are being abused. When you try to tell them something and you touch them, they report they were hit. Because of this law that protects them many are wandering and doing whatever they feel like. Because of this others act as if they are the authorities on everything. Because of this, the school administrators are getting in trouble to the point that they lose their jobs. I do not agree with this. (Calsoyas, 1992, p. 168)

Successful language revitalization programs have addressed problems with values such as those outlined by Walker, many of which are associated with non-Native education, by attempting to supplant them with traditional Native values. Levina Wilkins (2008) describes how, with the help of an elder, her school district put together a values curriculum based on her Yakama Nation's values of honesty, compassion, caution, courage, taking care, respect, thoughtfulness, humility, and service. Lipka et al.'s (1998, p. 126) study of Alaska Native education pointed out 
how Yup'ik teachers rejected the profuse "bubbly" praise promoted by outside [non-Native] teachers because traditional Yup'iks believed "overly praising will ruin a person.".

\section{Place-, Community-, Culture-based Education}

Any successful Native language revitalization program must address the questions raised in the preceding section regarding what will be taught using the medium of the Native language. In schools, will the program reflect the standard school curriculum or will it be indigenized and contextualized to reflect a particular Native community? As Wayne Holm, former director of the Navajo-English bilingual Rock Point Community School, noted, "If school is to be relevant, it has to deal with the realities of the land, the animals, and the people" (2006, p. 2). While such an education can be done largely in English as shown in the publication Between Sacred Mountains: Navajo Stories and Lessons from the Land (1982) by "storytellers and teachers" at Rock Point and transcribed by Sam and Janet Bingham, it makes sense to teach these same concepts in the Native language as well.

In a series of alternating essays in Power and Place: Indian Education in America, Vine Deloria, Jr. and Daniel Wildcat outline a rationale and framework for indigenous language revitalization programs. Deloria writes, "power and place produce personality" (Deloria \& Wildcat, 2001, p. 27). He contrasts the "Native American sacred view" with the "material and pragmatic focus of the larger American society" (Deloria \& Wildcat, 2001, p. v), and draws a distinction between a "unified" Indian worldview where everything is related versus a "disjointed sterile and emotionless world painted by Western science" (Deloria \& Wildcat, 2001, p. 2). Wildcat takes Deloria's vision of Indian education and proposes "an indigenization of our educational system" (Deloria \& Wildcat, 2001, p. vii). 
As a way of emphasizing our interconnectedness with environment and relationship to world, Deloria and Wildcat advocate both experiential learning involving example and observation as well as the importance of reciprocity/giving back. Both educational approaches not only reflect Native American world views, but are deeply embedded in tribal values. Deloria notes that "human personality was derived from accepting the responsibility to be a contributing member of a society" (p. 44) and that "education was something for the tribe, not for the individual" (Deloria \& Wildcat, 2001, p. 84).

In presenting their framework for indigenizing education, Deloria and Wildcat are directly challenging problems associated with non-native education and societal values. Wildcat describes the United States "as a nation of homeless people" who have places to live but don't know their neighbors (Deloria \& Wildcat, 2001, p. 67). Deloria goes on to write that they "live within a worldview that separates and isolates and mistakes labeling and identification for knowledge" (Deloria \& Wildcat, 2001, p. 133). Instead of just learning skills and facts, students in indigenous schools should develop a positive identity that includes having a sense of place both physically and socially; in fact, as Wildcat points out, the word "indigenous" means to be of a place (Deloria \& Wildcat, 2001, p. 31).

Even though Wildcat maintains, "there are good reasons for American Indian students not to discard knowledge traditionally held by their tribes, " he also calls on them not to "romanticize the past" (Deloria \& Wildcat, 2001, p. 8). While children need to respect their elders, they also need to learn from the failures of elders as well as their successes. Children are to be educated to "find home in the landscapes and ecologies they inhabit" (p. 71). Dr. Sandra Fox's (2000, 2001a, \& 2001b) K-12 Creating Sacred Places for Students curriculum guides 
published by the National Indian School Board Association focus on the type of curriculum called for by Deloria and Wildcat.

\section{Some Revitalization Efforts}

The following section discusses several examples of indigenous language revitalization programs and the cultural and values goals and educational philosophy that drive them. The first is the Apache language maintenance program studied by Nevins. She found that "awareness and participation in activities sustaining of family life" was viewed by the community as "central to knowing the Apache language" (2004, p. 280). "Knowing how to speak Apache is an index of the child's involvement in the intimate moral universe of family life" and "language loss is therefore interpreted as an indication of problems within the family" (2004, p. 282). Nevins notes that "Apache family-centered pedagogy teaches language by cultivating a child's awareness of the social world in which speaking is possible" (2004, p. 278). The community felt "that computers [used in the Apache language program] in the schools should not be allowed to take the place of parents and grandparents" (2004, p. 282). It wanted the Apache language program to strengthen families. Because the language program Nevins studied failed to focus on what the community saw as important, the tribal government ended it.

An Ojibwe language maintenance program was created to address not only language loss, but the social problems linked with it. An Ojibwe band saw the decline in the use of their language as correlating "with a loss of Ojibwe traditions, the unraveling of the extended family, depression among Band members, high drop out rates among Ojibwe students, and an increasing amount of gang activity among youth" (Bowen, 2004, p. 4). An Ojibwe Commissioner of Education argued that "By teaching the language we are building a foundation for a lifetime of 
productive citizenship.... Ojibwe values are inextricably linked to the language. These values, such as caring for the environment, healing the body and mind together, and treating all creation with respect are taught most effectively when they are taught in Ojibwe" (as quoted in Bowen, 2004, p. 4). The Ojibwe Advisory Board "firmly believed that writing Ojibwe was not as important as speaking it” (Bowen, 2004, p. 8). They wanted two fluent speakers in each classroom so conversation could be modeled for learners. And to make Ojibwe relevant to students' daily lives, they used music to make Ojibwe "cool."

Similarly, there are several Navajo examples of culture-based American Indian education implemented as part of the healing efforts to restore traditional family values. These programs show that the "either-or" idea that one either restores traditional values or assimilates into the non-Indian dominant society in order to achieve academic and economic success is a false dichotomy. In the 1970s, the all-Navajo Rock Point Community School Board concluded "that it was the breakdown of a working knowledge of Navajo kinship that caused much of what they perceived as inappropriate, un-Navajo, behavior; the way back, they felt was to teach students that system" (Holm \& Holm, 1990, p. 178). To counteract this breakdown, the Rock Point School Board established a Navajo-English bilingual program in their school that emphasized Navajo Social Studies and the Navajo beliefs about kinship. For the Navajo and other tribes, kinship through family and clans establishes rules for interacting in a respectful manner. And this interaction is reflected in the language itself. The Rock Point bilingual program was modified and transported to the Window Rock Public School. Studies of this program found that the Navajo immersion students showed more Navajo adult-like, responsible behavior than the Navajo students not in the immersion classes (Arviso \& Holm, 2001; Holm \& Holm, 1995). In addition to the Navajo social studies component of the immersion curriculum, a hands-on 
approach to math and science using manipulatives and experiments allowed students to understand and talk about what they were learning (see e.g., Reyhner, 1990).

The Window Rock Navajo immersion program started in 1986. The 200 students in the program, most of whom are English dominant, are immersed Navajo during kindergarten and first grade with curriculum based on the Navajo Nation's Diné cultural content standards as well as Arizona State academic standards. Some English instruction is started in second grade and by sixth grade half their instruction is in English (Johnson \& Wilson, 2005). Besides the improvement in student behavior reported, the immersion students showed higher Englishlanguage test scores than the non-immersion students in the same school district (Johnson \& Wilson, 2005; Johnson \& Legatz, 2006).

In contrast, observers of Window Rock's immersion program Kathryn Manuelito (Navajo) and Daniel McLaughlin observed that, "Navajo values are embedded in the classroom." A parent whom they interviewed,

noticed a lot of differences compared to the other students who aren't in the immersion program. [The immersion students] seem more disciplined and have a lot more respect for older [people], well anyone, like teachers. They communicate better with their grandparents, their uncles... [It] makes them more mature and more respectful. I see other kids and they just run around crazy. (as quoted in Reyhner, 2006d, pp. 79-80)

In Table 1 below Johnson and Wilson (2005) list the lessons learned in implementing the Window Rock immersion program, which teaches the first two grades all in Navajo and then introduces English as the students' Navajo proficiency develops further. 
Table 1. Lessons Learned from Navajo Immersion at Window Rock (Johnson \& Wilson, 2005, p. 31)

\section{WHAT WORKS:}

Learning Diné Language (speaking, reading and writing) helps the students to increase skills in English

Exposure to Diné Language increases language learning providing a language base for academic learning

Using Diné language to learn state academic standards increases rate of Diné language learning Constant exposure to Diné culture provides a feedback system to Diné language learning Using and reflecting on student's life experiences makes learning relevant for students The use of Diné language and integrating the Diné culture validates students' identity Standards Based System (Curriculum, Instruction, Assessment, Grading, Reporting)

\section{RESULTS:}

Language Proficiency in Diné /English Literacy in Diné/English

Retention \& High School Graduation Rate

Teacher Retention

Family Involvement in Responsibility for student learning

Diné values

Language Revitalization/Maintenance

\section{WHAT MAKES THE DIFFERENCE:}

Use of Diné (Heritage) language as medium of instruction

Consistent integration of Diné (heritage)

culture in instruction

Strong parent involvement motivates student learning (child \& parents learning Culture

Knowledge together)

Visionary leadership

The Navajo Nation's Education Division lists its preschool through college cultural learning goals approved in 2000 by the Navajo Nation's Education Committee in T'áá Shá Bik'ehgo Diné

Bí Ná nitin dóó Íhoo’aah, which translates Diné Cultural Content Standards (Office of Diné Culture, 2000). The preface to the standards states, “The Diné Cultural Content Standards is predicated on the belief that firm grounding of native students in their indigenous cultural heritage and language is a fundamentally sound prerequisite to well developed and culturally healthy students" (Office of Diné Culture, 2000, p. v). The empowering values of the Diné individual to be taught include being "generous and kind," "respecting kinship," "being a careful listener," and "having a balanced perspective and mind" as well as not being lazy, impatient, 
hesitant, easily hurt, shy, or mad. Diné individuals are to respect the sacred, have self-discipline, and prepare for challenges (Office of Diné Culture, 2000, p. 80).

In The keynote address on March 9, 2004 at the U.S. Office of Indian Education Program's Third Symposium on Language and Culture Preservation, the theme of which was “Journeying Home: Creating Our Future From Our Past,” Navajo elder and statesman Jack Jackson summed up the goal of values based Dine language programs. He noted that, at Diné College, the Navajo Nation's tribal college, they are "in a search to create our future based on our past." He emphasized the importance of teaching Navajos the Navajo philosophy of "Ké," of being a balanced person. This involves examining beauty before oneself, beauty behind oneself, beauty underneath, beauty above, and beauty around, with the goal of becoming a balanced person who walks in beauty.

Native Hawaiians have also been very active in seeking to restore their traditional values through language immersion programs. The Pūnana Leo (Hawaiian Immersion Language Nest) movement begun in 1983 in Hawaii is built around re-establishing the Hawaiian philosophy of life as indicated by their mission statement:

The Pūnana Leo Movement grew out of a dream that there be reestablished throughout Hawai' $i$ the mana of a living Hawaiian language from the depth of our origins. The Pūnana Leo initiates, provides for and nurtures various Hawaiian Language environments, and we find our strength in our spirituality, love of our language, love of our people, love of our land, and love of knowledge. ('Aha Pūnana Leo, 2010) 
From its start with Hawaiian preschools in the 1980s, Hawaiian language immersion classrooms were extended into successively higher grades until the first five K-12 immersion students graduated from high school in 1999. Students entering the program are mostly English speakers and they are immersed in Hawaiian from kindergarten to grade five with some English introduced after grade five. In a case study of a new immersion teacher at a Hawaiian immersion school, Keiki Kawai'ae'a and Angayuqaq Oscar Kawagley observed the interaction between approaches to teaching and the values being transmitted,

One feels comfortable in entering the [immersion] school. Everyone is friendly, paying attention to the task at hand. The students work cooperatively on various projects. One project was developing a story using the Hawaiian language to describe what is happening and drawing a picture to go with it. The finished products are hung outside the classroom for everyone to see and enjoy. The few teachers observed were easy going, moving around from one individual or group, giving suggestions, answering questions, all done in a conversational tone even when correcting a child. Everyone is engaged in a easy going but disciplined process. Self-discipline becomes obvious as one observes, which is the desired outcome. (as quoted in Reyhner, 2006d, p. 80)

Kawai'ae'a and Kawagley found that "people have realized that they have to revitalize their language and culture for healing to begin" (as quoted in Reyhner, 2006d, p. 69). They observed:

At the Hawaiian immersion school, the day began and ended with traditional Hawaiian protocol-a Hawaiian chant, a positive thought, and a prayer to open and close the day. 
Included in the morning protocol was the formal request chant and reply in Hawaiian to enter the school. This opening protocol set the mood for the day by helping all to focus and reflect on the task of learning, teaching and leading with good thoughts, intentions and feelings, and a cooperative spirit. The school day ended with a chant to attune them to another realm, that of home, family, friends, and place with all its different idiosyncrasies. The well-being of the whole group through active participation at the piko (a spiritual gathering place) was a part of the healing, health and lifelong learning daily experiences for the total learning community — students, teachers, support staff, families and guests. (as quoted in Reyhner, 2006d, p. 78)

The researchers commented that "The Hawaiian language is the living language of the school," noting the pivotal role it plays in the curriculum:

The language best expresses the thought world of the ancestors and thrusts them into the Hawaiian worldview. This is the language of connectedness, relatedness and respect. The language provides the cultural sustenance and the lens from which the dynamics of the school community has evolved. The language is formed by the landscape with its soundscape and therefore, conducive to living in concert with Nature. The families working together as part of the total learning community become an integral part of the learning environment... The language shapes and nurtures the school learning community as a complete and whole entity. (unpublished case study by Keiki Kawai'ae‘a \& Angayuqaq Oscar Kawagley, 2006) 
According to Kawai'ae'a and Kawagley, "The program is family-based, enrolling the families rather than the individual student for overall program of language and cultural development." The seven guiding cultural pathways for Hawaiian educational success developed with the assistance of küpuna (elders) from 16 cultural guidelines are:

\section{1. 'IKE HONUA (Value Of Place):}

Developing a strong understanding of place, and appreciation of the environment and the world at large, and the delicate balance necessary to maintain it for generations to come.

\section{2. 'IKE HO'OKŌ (Value of Applied Achievement):}

Measuring success and outcomes of our learning through multiple pathways and formats.

\section{3. 'IKE KUANA'IKE (Value of Cultural Perspective):}

Increasing global understanding by broadening the views and vantage points from which to see and operate in the world. (Developing the cultural lens from which to view and operate in the world)

\section{4. 'IKE MAULI LĀHUI (Value of Cultural Identity):}

Strengthening and sustaining Native Hawaiian cultural identity through practices that support the learning, understanding, behaviors, and spiritual connections through the use of the Hawaiian language, culture, history, traditions and values.

5. 'IKE NA'AUAO (Value of Intellect):

Instilling and fostering a lifelong desire for knowledge and wisdom, while strengthening a thirst for inquiry and knowing. 
6. 'IKE PIKO'U (Value of Personal Identity):

Promoting personal growth and development, and a love of self, which is internalized and develops into a sense of purpose/role. (Growing aloha and internalizing kuleana to give back)

7. 'IKE PILINA (Value of Relationships):

Enriching our relationships between the people, places and things that influence our lives through experiences that ground us to our spirituality and connect us to our genealogy, culture, and history through time and place. (Hawai 'i Guidelines, 2002, p. 1)

On a smaller scale, the Cuts Wood School on the Blackfeet Nation in Montana immerses its students in their Blackfeet language. Its Web site declares:

Cuts Wood School is nationally recognized as a successful and effective model for Native language immersion with a multi-generational approach. Cuts Wood School's mission is to use the Blackfeet language as the tool (not object) of instruction within a local context to produce fluent speakers of the Blackfeet language. In operation since 1995, Cuts Wood School offers full day programming for children age 5-12. Our objective is to develop highly skilled learners who are knowledgeable in both Blackfeet and world academia. (Piegan Institute, 2010) 
Values are also emphasized. The Cuts Wood School avoids competition, "a form of violence," as well as hierarchal concepts, ranking, and punitive designations. The school has found "that learned knowledge [in Blackfeet] will transfer to English” (Kipp, 2009, p. 5).

\section{Conclusion}

Students of whatever race or culture who are disconnected from their traditional values are only too likely in modern America to pick up unhealthy values of consumerism, consumption, competition, comparison and conformity from the barrage of popular culture transmitted by television, movies and the Internet. In 1998 the National Research Council reported that immigrant youth tend to be healthier than their counterparts from nonimmigrant families. It found that the longer immigrant youth are in the U.S., the poorer their overall physical and psychological health. The more "Americanized" they became, the more likely they were to engage in risky behaviors such as substance abuse, unprotected sex, and delinquency (Hernandez \& Charney, 1998). There is evidence that this pattern holds true for Native youth, with those who are less assimilated into the dominant culture doing better in school and in life. As Vine Deloria wrote, "A society that cannot remember and honor its past is in peril of losing its soul" (1994, p. 272). A primary goal and impetus of indigenous language revitalization programs is to re-establish this lost link to traditional values and culture.

The U.S. Secretary of Education's Indian Nations at Risk Task Force's (1991) second of ten goals was that "By the year 2000 all schools will offer Native students the opportunity to maintain and develop their tribal languages and will create a multicultural environment that enhances the many cultures represented in the school." At the time of writing, this goal is still far 
from fruition despite the evidence outlined in this article that immersion schools help indigenous students succeed in a variety of ways.

While academic knowledge and test scores are important, it is students' behavior towards others that is the paramount importance because it is a determinant of how individuals use the knowledge they have gained. The future of tribal individuals, communities, and nations as well as the world depends on our ability to get along with each other and work together for a better future. Well thought out and implemented indigenous immersion programs can restore positive traditional values, develop students' reasoning ability, and teach solid academic content. Pease (2004, p. 16) concluded her research of immersion schools by stating that "immersion improves overall educational achievement, strengthens family ties, and increases retention rates, keeping Native students in school who might otherwise drop out." While more research needs to be done on the academic advantages of immersion programs, students in them tend to do well academically as well as behaviorally (see e.g, Johnson \& Legatz, J., 2006 \& Johnson \& Wilson, 2005).

\section{References}

Adams, D.W. (1995). Education for extinction: American Indians and the boarding school experience, 1875-1928. Lawrence, KN: University Press of Kansas.

'Aha Pūnana Leo. Mission Statement. Retrieved August 4, 2010, from http://www.ahapunanaleo.org/eng/about/about_mission.html

Alvord, L. A. \& Van Pelt, E. C. (1999). The scalpel and the silver bear. New York: Bantam. Ambler, M. (2004). Native languages: A question of life or death. Tribal College, 15(3), 8-9. 
Arviso, M., \& Holm, W. (2001). Tséhootsooídi Ólta'gi Diné Bizaad BÍhoo'aah: A Navajo immersion program at Fort Defiance, Arizona. In L. Hinton \& K. Hale (Eds.), The green book of language revitalization in practice (pp. 203-215). San Diego, CA: Academic.

Bowen, J.J. (2004). The Ojibwe language program: Teaching Mille Lacs Band youth the Ojibwe language to foster a stronger sense of cultural identity and sovereignty. Cambridge, MA: The Harvard Project of American Indian Economic Development, John F. Kennedy School of Government/Harvard University.

Between sacred mountains: Navajo stories and lessons from the land. (1982/1994). Rock Point, AZ: Rock Point Community School. Reprinted by University of Arizona Press, Tucson. Calsoyas, K. (1992). The soul of the Indian. (Ed.D. dissertation, Northern Arizona University). Declaration on the Rights of Persons Belonging to National or Ethnic, Religious and Linguistic Minorities (1993). G.A. Res. 47/135, U.N. GAOR, 47 ${ }^{\text {th }}$ Sess., Supp. No. 49, at 210, U.N. Doc. A/47/49. Retrieved January 20, 2009, from http://brj.asu.edu/archives/1v21/UN.html

Deloria, Jr., V. (1994). God is red: A Native view of religion. Golden, CO: Fulcrum.

Deloria, Jr., V., \& Wildcat, D.R. (2001). Power and place: Indian education in America. Golden, CO: Fulcrum Resources.

Fox, S. J. (2000). Creating a sacred place to support young American Indian and other learners in grades k-3 (Vols. 1 \& 2). Polson, MT: National Indian School Board Association.

Fox, S. J. (2001a). Creating a sacred places for children in grades 4-6. Polson, MT: National Indian School Board Association.

Fox, S. J. (2001b). Creating a sacred places for students in grades 9-12. Polson, MT: National Indian School Board Association. 
Freeman, C., \& Fox M.A. (2005). Status and trends in the education of American Indians and Alaska Natives. U.S. Department of Education, National Center for Educational Statistics.

Grande, S. (2004). Red pedagogy: Native American social and political thought. Lanham, MD: Rowman \& Littlefield.

Hawai 'i Guidelines for Culturally Healthy and Responsive Learning Environments. (2002). Retrieved January 20, 2009, from http://www.olelo.hawaii.edu/olelo/nhmo.php

Hernandez, D.J., \& Charney, E. (Eds.) (1998). From generation to generation: The health and well-being of children in immigrant families (Committee on the Health and Adjustment of Immigrant Children and Families, Board on Children, Youth, and Families, National Research Council and Institute of Medicine.) Washington, DC: National Academy. Holm, W. (2006). The "goodness" of bilingual education for Native American children. In T.L. McCarty \& O. Zepeda (Eds.), One voice, many voices: Recreating Indigenous language communities (pp. 1-46). Tempe, AZ: Arizona State University Center for Indian Education.

Holm, A., \& Holm, W. (1990). Rock Point, A Navajo way to go to school: A valediction. ANNALS, AAPSS, 508, 170-184.

Holm, A., \& Holm, W. (1995). Navajo language education: Retrospect and prospects. Bilingual Research Journal, 19(1), 141-167. Retrieved January 20, 2009, from http://www.ncela.gwu.edu/pubs/nabe/brj/v19/19_1_holm.pdf

Hubert, A. (2003). Raising America: Experts, parents, and a century of advice about children. New York: Alfred A. Knoff. 
Indian Nations at Risk Task Force. (1991), Indian nations at risk: An educational strategy for action. Washington, DC: U.S. Department of Education. Retrieved January 20, 2009, from http://www.tedna.org/pubs/nationsatrisk.pdf

Institute For Government Research. (1928). The problem of Indian administration. Baltimore, MD: John Hopkins. Retrieved January 20, 2009, from http://www.alaskool.org/native_ed/research_reports/IndianAdmin/Indian_Admin_Problm s.html

Johnston, B. (2002). The rise and fall of a Dakota Immersion pre-school. Journal of Multilingual and Multicultural Development, 23(3), 195-213.

Johnson, F., \& Legatz, J., (2006). Tséootsooí Diné bi’ólta. Journal of American Indian Education, 45(2), 25-33.

Johnson, F., \& Wilson, J. (2005). Navajo immersion in the Navajo Nation. NABE News, 28(4), 30-31.

Kipp, D. (2009). Encouragement, guidance and lessons learned: 21 Years in the trenches of indigenous language revitalization. In J. Reyhner \& L. Lockart (Eds.), Indigenous language revitalization: Encouragement, guidance and lessons learned (pp. 1-9). Flagstaff, AZ: Northern Arizona University. Retrieved on January 20, 2009, from http://jan.ucc.nau.edu/ jar/ILR/

Lipka, J., Mohatt, G., \& the Ciulistet Group. (1998). Transforming the culture of schools: Yup'ik Eskimo examples. Mahwah, NJ: Lawrence Erlbaum.

Littlebear, R. (1999). Some rare and radical ideas for keeping Indigenous languages alive. In Revitalizing indigenous languages (pp. 1-5). Flagstaff, AZ: Northern Arizona University. Retrieved January 20, 2009, from http://jan.ucc.nau.edu/ jar/RIL 1.html 
Mankiller, W. (2004). Every day is a good day: Reflections by contemporary Indigenous women. Golden, CO: Fulcrum.

Matsuura, K. (2008). Message from Mr Kö̈chiro Matsuura. Retrieved January 20, 2009, from http://portal.unesco.org/culture/en/ev.php$\underline{\text { URL ID=35559\&URL DO=DO TOPIC\&URL SECTION=201.html }}$

Midgette, S. (1977). The Native languages of North America: Structure and survival. In D. Morrison (Ed.), American Indian studies: An Interdisciplinary Approach to Contemporary Issues. New York: Peter Lang.

Nevins, M.E. (2004). Learning to listen: Confronting two meanings of language loss in the contemporary White Mountain Apache speech community. Journal of Linguistic Anthropology, 14(2), 269-288.

Office of Diné Culture, Language \& Community Service, Division of Diné Education. (2000). T'áá Shá Bik'ehgo Diné Bí Ná nitin dóó Íhoo’aah (Diné Cultural Content Standards). Window Rock, AZ: Author. Retrieved January 20, 2009, from http://www.odclc.navajo.org/view taa yellow.htm

Pease, J. (2004). New voices, ancient words. Tribal College, 15(3), 15-18.

Piegan Institute. Cuts Wood School. Retrieved August 4, 2010 from http://www.pieganinstitute.org/cutswoodschool.html

Platero, D. (1975). Bilingual education in the Navajo Nation. In R. C. Troike \& N. Modiano (Eds.), Proceedings of the first inter-American conference on bilingual education (pp. 5661). Washington, DC: Center for Applied Linguistics. 
Powell, J.W. (1896). The need of studying the Indian in order to teach him. In Annual Report of the Board of Indian Commissioners (pp. 109-15). Washington, DC: U.S. Government Printing Office.

Reyhner, J. (2008). Promoting human rights through Indigenous language revitalization. Intercultural Human Rights Law Review, 3, 152-189.

Reyhner, J. (2006a, May). Humility vs. self esteem: What do Indian students need? Indian Education Today, 33-36. Retrieved January 20, 2009, from http://jan.ucc.nau.edu/ jar/AIE/IEThumility.html

Reyhner, J. (2006b). Education and language restoration. Philadelphia, PA: Chelsea House. Reyhner, J. (2006c, March). Creating sacred places for children. Indian Education Today, 19-20. Retrieved January 20, 2009, from http://jan.ucc.nau.edu/ jar/AIE/IETplaces.htm Reyhner, J. (2006d). Issues facing new Native teachers. In D. Beaulieu \& A.M. Figueira (Eds.), The power of Native teachers (pp. 63-92). Tempe, AZ: Center for Indian Education, Arizona State University.

Reyhner, J. (1990). A description of the Rock Point Community School Bilingual Education Program. In J. Reyhner (Ed.), Effective language education practices and Native language survival (pp. 95-106). Choctaw, OK: Native American Language Issues. Retrieved January 20, 2009, from http://jan.ucc.nau.edu/ jar/NALI7.html

Reyhner, J., \& Eder, .J. (2004). American Indian education: A history. Norman, OK: University of Oklahoma.

Shirley, J. Jr., (2005, March 30). Another viewpoint: Red Lake tragedy points to loss of traditional ways, Navajo Hopi Observer, 25(13), 5. 
Skutnabb-Kangas, T. (2000). Linguistic genocide in education-or worldwide diversity and human rights. Mahwah, NJ: Lawrence Erlbaum.

Universal Declaration of Human Rights. (1948). G.A. Res. Res. 217A, at 71, U.N. GAOR, $3^{\text {rd }}$ Sess., U.N. Doc. A/810 (Dec. 10, 1948). Retrieved January 20, 2009, from http://www.un.org/Overview/rights.html

United Nations Declaration on the Rights of Indigenous Peoples, G.A. Res. 61/295 (2007, Sept. 13), Retrieved January 20, 2009, from http://www.un.org/esa/socdev/unpfii/en/declaration.html

Wilkins, L. (2008). Nine virtues of the Yakima Nation. Democracy \& Education, 17(2), 29-32. Yazzie, E.P. (2003). Missionaries and American Indian languages. In J. Reyhner, O. Trujillo, R.L. Carrasco \& L. Lockard (Eds.), Nurturing Native languages (pp. 165-178). Flagstaff, AZ: Northern Arizona University. Retrieved January 20, 2009, from http://jan.ucc.nau.edu/ jar/NNL/NNL 14.pdf

Yazzie, E.P. (1995). A study of reasons for Navajo language attrition as perceived by Navajo speaking parents. (Ed. D. dissertation, Northern Arizona University). 